\title{
Concordia Discors or Teach the Conflicts. Reflections on the Validity and Heuristics of Scholarly Conflict
} By Thomas Hoffmann

What kind of methodological and axiological lodestars would the academic community of Islam scholars do wise to observe in the current situation of intense political and medial 'discursivization' of Islam and Muslims? How are 'we' - our imagined scholarly community - to navigate in a field that over the past decades has moved from a fairly select and exclusive island to an increasingly deceitful and contested archipelago? ${ }^{1}$ Surely the first thing to do must be critical self-reflection, asking ourselves questions about our trade's ideological and political implications and about the truths we hold selfevident.

The second thing to do is also rather 'self-centred', albeit in a less meta-wise way, and that is to try to decide and spell out and commit oneself to some kind of research agenda. By forwarding some programmatic proposals on a research commitment that could be epitomized under Horace's old expression Concordia Discors, 'Concord in Discord' (Epistularum 20 BC: I. xii, 19) I hope to make clear at least my own position. In the end, there is, to quote Harold Bloom, "no method but yourself" (Spirer 1989). Horace's petite maxim, recycled from even older Greek philosophers, basically claims that elements of conflict and heterogeneity can and should be forged into a kind of jarring unity - not only in society at large but in the Academia in particular. It is, in other words, a decidedly positive take on conflict and discord. The up-dated version of the Horacian stand, which I want to endorse, is much beholden to the suggestions of Gerald Graff, a North American professor of English and Education. Suggestions that he put forth in a book titled Beyond the Culture Wars: How Teaching the Conflicts Can Revitalize American Education. This prize-winning, influential, pragmatic and calmly theorized work tallies well with a relative recent political theory that is sometimes labelled Agonistic Pluralism, or simply Agonism.

For this reason, I propose to promote the Islamologist - holding any attempts to define this sweeping figure in abeyance - as someone who should aspire to exercise and reconcile two important principles or attitudes engagement and argument, two principles the 
wording of which will prove pertinent below. This also pertains to an acute and unsettled debate on the role of academic critique vis-à-vis religion.

Realizing that, at the end of the day, such programmatic proposals may very well fare the destiny of most proposals, we must ask ourselves what is to be gleaned from the present state of affairs. Instead of reflex lamentations (in times of abundant funding and political receptivity) and propagation of the myth of a field besieged by ill willed media, politicians, vox populi, and the proverbial hidden hands, we ought to reconsider the current state of affairs. Part of the solution lies, I believe, in what is almost a Freudian approach, namely that we try to tease out - and teach out - the sore issues, acknowledge the conflicts and the issues at stake, in short all the awkward materials, and then talk/argue ourselves into some kind of heightened understanding and mutual scholarly recognition which should not be interpreted as sheer harmony and agreement, but harmony in discord, a conflictual consensus, as it were. A talking cure endorsing conflict before reconciliation. Otherwise, researchers, students, media, and the public will be prone to disseminate hostile myths and half-truths about one another or, at least more than hitherto done.

\section{Grammatical Passives and the Predator-Prey Scenario}

Being a historian of religion with certain philological interests, and having worked over the past five years on the subject of religion and rhetoric, in particular the Qur'ânic text (e.g., Hoffmann 2007), it has perhaps been a work-related injury that made me attend to the extensive amounts of grammatical and semantic passives that roams the academic and semi-academic discourse (especially in short texts like call-texts and book blurbs) on Islam and Muslims. A call text that I recently received could be used as an example of this kind of grammatical 'passivization' of our scholarly field (pace its many astute and good points): "Islam and Muslims have increasingly become subjects of political and media debate... Islam is used in the political and media discourses... scholars of Islam navigate in a highly politicised field... Islamic studies scholars are frequently positioned as political actors...A central question would be whether Islamic studies research... is forced into defensive positions by political agendas?" (my italics). ${ }^{2}$ 
The first question that comes to my mind is: why choose these passives and passive-like constructions (Wales 2001: 288-89)? Since we have a choice in language, we must ask what is to be gained by using the passive instead of the active. We know that the meaning can be paraphrased more or less accurately irrespective of grammatical voice. However, passive constructions hold certain strategic assets; they are useful when the specific agent is not known or only vaguely contoured in the mind of the speaker such as, for instance, when we employ notions such as 'the Danish society,' 'the public sphere,' 'power,' 'tendency,' and even our Foucaultian favourite, 'discourses.' In so-called critical linguistics (a.k.a. critical discourse analysis) (e.g., Fowler and Kress 1979: 185-213), researchers are particularly interested in the extent to which the choice of active or passive, with the differences of focus of emphasis, affects the perspective of the action so as to influence the reader's view of events. In other words, the choice may betray ideological bias.

My immediate construal of the passives mentioned above is a virtual prey-and-predator scenario. An inherently vulnerable and disfavoured field - incl. researchers and their research objects - are engulfed (cf. "navigate"), manipulated (cf. "positioned"), and constrained (cf. "forced") by strong and often nameless agents and forces. Grammatical passives and rhetoric like this, however, is only a fragment of a more encompassing scholarly discourse thriving on notions like misrepresentation, prejudice, hegemony, discrimination and various -isms (e.g., orientalism, eurocentrism, racism, Islamophobia, Zionism). To be sure, each and every one of these notions is warranted but the flipside to these concepts is the all too willing abolishment of concepts like autonomy, determination, motivation and the like. We witness a situation where these notions inscribe almost any subject (from people to ideas) into a state of sheer compliance, of victimisation, of powerlessness and tokhm nadarad. ${ }^{3}$ It is a strangely paradoxical situation because these fashionable notions suggest a keen awareness of issues political while simultaneously revealing a certain reluctance to acknowledge the political nature of the whole enterprise. What rears its head in each and every of these examples is nothing less than the political, yet is as if the conflictual, antagonistic quality of the political is shunned and that any positive potential for this conflict-ridden stuff is denied. ${ }^{4}$ Like Graff I believe that open and fairly conducted conflict is the shibboleth to a productive research milieu rather than a poisonous barrier. 
A telling example of this reluctance is a recent publication with the relevant title Teaching Islam (in American Academy of Religion's Teaching Religious Studies Series). Edited by Brannon Wheeler (who in fact happens to be a professor at the United States Naval Academy) and including a number of reputed researchers and experienced teachers (inter alia Jonathan E. Brockopp, Jane Dammen McAuliffe, Michael Sells, Carl W. Ernst Marcia K. Hermansen), it seeks to address basic questions of how Islam should be taught, providing practical information as well as more theoretical considerations. By no means is it a publication which shun delicate issues, for instance, how to incorporate so-called revisionist research (e.g., Wansbrough, Crone, Hawthing \& co.) in class situation with Muslim students (Lewinstein: 46-60). Yet none of the twelve articles deal explicitly with the political contestations that is part and parcel of the contemporary field, whether the fights of titans between Bernard Lewis and Edward Said, the case of Daniel Pipes' Campus Watch initiative or the suing of the University of North Carolina for making Michael Sells' Approaching the Qur'ân required summer reading for first year students. ${ }^{5}$

Instead of viewing ourselves as preys of faceless and shadowy politicisation, we should perhaps openly acknowledge the political as something that comes with the territory (at least great stretches of that territory) - and rightly so. Subsequently, we must be prepared to face and engage politicisation [and] criticism from every angle of our society, the scholarly as well as the common society. That is, from politicians to peers, from more or less 'esoteric' and conspirational bias-critics to critical tests of prediction and validity.

With a few notorious exceptions, we as researchers should be careful not to stage ourselves as hunted prey, even though this may have some short-sighted strategic advantages. What I fear is that it can prove harmful to the self-conception of the field in general if future students are raised in this atmosphere. In fact, when I take a look at the field, I see quite a complex and pro-active field beyond the prey-predator-divide. Indeed, some of the politicisation-allegations should be worn as real badges of honour and as a sure indication that the field is as strong and influential as ever. Far from being the erstwhile Orkideen-Beruf, the field is now somewhat of a vigorous player: it experiences abundant funding, is involved in close cooperation with the higher and heavier ranks of state apparatus (from the Foreign office to the military and various governmental committees) and commercial agents (e.g., from national businesses to giants like the Seven Sisters), is get- 
ting increasingly engaged in corporate consulting, and has easy access to mass media, where we can forward our views with a certain authority. The so-called think tanks are still a predominantly American phenomenon, ${ }^{6}$ but they may very well develop on the European horizon as well. Do I need to say that this new momentum of possibilities in terms of financial support and employment does not come about without a price. The ground rule, still, is that though we might be able to choose our adversaries, unfortunately we cannot choose their objects of criticisms and concerns. This is of course a source of frustration, but not one that should surprise us too much - rather it should sharpen our arguments or, now and then, give us the opportunity to revise our self-evident truths.

On the subject of 'defensive positions' mentioned earlier, I should say, that there is nothing inherently wrong with being defensive - except if one prefers being the opposite. Defending and arguing for our theses (from hypotheses to doctoral theses) is not only a metaphorical expression, it is a genuine academic mode of conduct. To be sure, this is not to say that we cannot be tricked into unfair defensive positions, for instance by more or less subtle guilt-of-association or by being compelled to answer questions like 'do you still beat your wife' as when one is asked if you are an islamapologist (aka 'halal-hippie'position) or the opposite, the infamous islamophobic position.

\section{Concordia Discors and the Adab of Engagement and Argument}

Once again, let us turn our attention to our Latin maxim Concordia Discors, 'Concord in Discord.' The philosophical stance behind this notion is basically that elements of conflict and heterogeneity can be forged into a kind of jarring unity - that, indeed, the perpetual strife between these elements is something to be welcomed rather than ousted; primarily because it fosters academic competitiveness, analytical edge, and, of course, a plurality of perspectives that - hopefully - instil in us not only cool super-vision of the field but also that fortunate confusion we need in order to generate new hypotheses. Even the Prophet agrees with me on this issue, in a famous hadith Muhammad is reported to have said that "In my community, disagreement (ikhtilâf) is a sign of divine mercy" (van Ess 2006: 8). According to Graff, how, anyway, could it be otherwise given the great range of juxtaposing and clashing theories, methodologies, and eo ipso ideologies, within the walls of the university. While one humanist would prefer to speak of 'traditional 
moral themes,' another one would disapprove such phrasings as both static and conformist and rephrase it as 'patriarchal discursive practices,' a much more gender-sensitive and agency-oriented perspective.

For these reasons, I propose to promote the Islamic studies scholar as someone who should aspire to exercise and balance two important research commitments, namely engagement and argument. Both should be construed as puns; the former, i.e., 'engagement,' because it denotes 'being committed and involved' but also 'being engaged in a struggle' - this constitutes the political aspect of our trade. The latter, i.e., 'argument,' is a pun too because it denotes 'a reason or set of reason that somebody uses to show that something is true or correct' as well as 'heated and sometimes ruthless discussion' - this, I believe, constitutes to a large degree the academic aspect of our trade. The governing principle behind this commitment to engagement and argument is the recognition and promotion of what could be labelled agonistic pluralism in the academe. The scholarly, as it were, $a d a b^{7}$ of a good row.

My argument also pertains to an on-going debate about how to pit academic critique in regard to religion (and its historical instantiations) and how the notion of causality vis-àvis historical explanation should be employed. Right now great stretches of Islamic studies seem to be hesitant as how to place critique within their field - partly because we have become aware of the tough ideological issues at stake, partly because we have become increasingly aware of our metier's research history (e.g., colonial engagements, overtly religious bias or other vices), and partly because - I would claim - many of us still entertain a strong ambivalence vis-à-vis the religious ontologies, epistemologies and practices. Though many of us probably agree that as for religion in general, we should repeating Russell McCutcheon's apt phrase - act as critics, not caretakers (McCutcheon: $2000,167 \mathrm{ff}$.), yet some of us begin to feel uneasy when critique is directed against certain religious categories and groups, for instance monotheism. Think of Egyptologist Jan Assmann and his notion of the so-called Mosaic distinction with its claims on monotheistic intolerance, hatred, and violence (Assmann: 2003) ${ }^{8}$ or Bernard Lewis' concept of triumphalist religions (Lewis: 2003), or the sociologists of religion, Charles Glock and Rodney Stark, and their sociological notion of so-called particularistic religions, e.g., Christianity's anti-Semitic inclinations (Glock \& Stark: 1966). So when researchers begin 
to probe the deep reservoirs of religious violence and bodies of legitimizing texts (e.g., Avalos: 2005; Schwartz: 1998) matters becomes highly precarious. And then some of us all too readily begin to take recourse to what Avalos aptly has called crypto-essentialism, that is, the propagation of a sleight-of-hand essentialism while at the same time proclaiming not to do so $(2005,26-27)$. One common example of this is found in works and statements in which undesirable and mortifying elements in some religious traditions are written off as 'deviations,' 'abuses' or downright 'perversions' - the suggestion being that a sound bona fide kernel (i.e., the covert crypto-essentialism) forever remains. At that point, we are on the verge of relapsing into what Donald Wiebe repeatedly has decried as a religionist agenda, namely that religion is only to be understood, not criticised, that religion, since it is so human and global, must be treated as a challenging potential rather than as a severe problem (e.g., Wiebe, 1999)

Trying to recast these thoughts among researchers, for the sake of our scholarly fields, I endorse the ideal of a research milieu, which is a battleground of ideas rather than artificial consensus, but also - even more important - a milieu promoting the commitment always to listen attentively to one's adversaries. Not only to one's own playful Devil's Advocate but also our real academic adversaries. A milieu where we can read and learn from Edward Said as well as Bernard Lewis, read Negri \& Hardt's Empire along with Huntington's The Clash of Civilisations without the ritual sweeping denunciations - but of course critically. Despite our personal adversaries' flagrant theoretical or methodological flaws and biases, we must acknowledge that many theories, theses, and schools precisely because of their biases and flaws - have produced valuable insights that others could not have produced. Said is the epitome of this scholarly paradox, being both the seriously flawed critic (e.g., Robert Irwin's critique of Said: 2007, 277-309) and the innovative, powerful scholar. Being exposed to each others' premises and arguments can of course lead to stubborn entrenchment and demonization of the Other (scholar), but it might also open up for sound revision and sharpening of analyses. It may look like that I am advocating for some kind of irenic intellectual reconciliation and tolerance. ${ }^{9}$ Not so, it is rather the eclectic manoeuvres and the constant revisions that should characterize our academic pursuits. 


\section{A False Courtesy or Teach the Conflicts!}

When we as researchers engage in meta-debates like these, we naturally talk a lot about ourselves, predominantly in the role as researchers. Rather unsurprising, we also speak quite a lot about Islam and Muslims and public and political institutions at large. We must, however, also speak about the students and the curricula. First, however, I must admit that my teaching experience does not amount to more than ten courses or so and my reflections on the overall subject of politicisation, teaching and research has been more prompted by my experience with the scholarly milieu as such and the public debates that most of us have been engaged in in one way or another. However, this fifteen year old book, Beyond the Culture Wars, by Gerald Graff (who, by the way, is a liberal and professed anti-conservative) has inspired me much. In his book, he forwards this central thesis "that the best solution to today's conflicts over culture is to teach the conflicts themselves, making them part of our object of study and using them as a new kind of organizing principle to give the curriculum [...] clarity and focus..." (Graff 12)

As far as I can see, what is going on in Denmark (and Europe) in these years is something similar to what the Americans call culture wars. Culture wars are broadly contested issues in our late-modern societies and are generated by polemics about issues such as gender, race, nationality, class, and now also religion, especially Islam. Islamic studies researchers can of course avoid these polemical debates, but some kind of involvement should be encouraged by the specific scholarly milieu and the Academia at large. Partly because we are citizens and part of national societies (whose taxpayers support us), partly because we need to abandon pretend-neutrality concerning the respective religions' hermeneutic positions. In agreement with influential scholars like Mohammed Arkoun and Jane D. McAuliffe, I hold that non-Muslim researchers' reluctance to engage in hermeneutic activity constitute "a false courtesy that undermines the effort of their Muslim colleagues and supports self-justifying orthodoxies" (McAuliffe: 2004).

However, within the culture war-warzone another fight is going on; a fight that concerns the study of ]religion, including Islam. Islamic studies in Denmark is to some degree witnessing the same fight, which has been going on in the States for several years. Part of that conflict was launched by Middle East scholar Martin Kramer's harsh - some would say perfidious - critique of Middle East studies, Ivory Towers on Sand. The Failure of 
Middle Eastern Studies and America (2001), and later followed up by another MEscholar, that is, Daniel Pipes and his pro-Israel and conservative Campus Watch initiative (the reverse instance of the $\mathrm{P}$ (olitical)C(orrectness)-movement that has swept across the American campus). Though Campus Watch presents itself as a helping hand to Middle East studies in the States, addressing five core-problems (analytical failures, mixing of politics with scholarship, intolerance of alternative views, apologetics, and the abuse of power of students), it seems to have spiralled down into a rather obsessive organisation of ressentiment, fraudulent misreadings and ad hominem attacks.

The big difference is, however, that whereas it was Middle East scholars who started the debates and controversies in the States, in Denmark it has rather been certain newspapers, commentators, and politicians, mostly of conservative and populist rightist orientation (with a notable contingent of 'converted' leftists). These first strikes have left the local academic field in somewhat stunned and, so it seems, injured, but it is also a clear indication that the gap between Danish public and the ivory tower has closed for good (and for bad). Thus, more than ever the field is getting involved in governmental programs and consulting. Add to that a heightened involvement in corporate life. And due to a general trend in the media and clever use of individual talent (some even say that a measure of 'charisma' should be included as well) select researchers have gained strong media platforms from where they can communicate to the public. In other words, far from being an obscure, exotic field, it has grown immensely popular and has furthermore gained access to power circles we could only fantasise about a few decades ago. This of course gives way to high political risk, but also high pay (not necessarily in economical terms but in terms of influence and scholarly status).

Let me adduce an example that I find instructive when it comes to the debate about politicisation and academic teaching. Around a year ago we witnessed a case, where a tenured university teacher (teaching comparative religion and sociology of religion) was attacked in the media for being overly political in the lecture hall. This case (which had no bearings to Islamic studies and soon turned out not to be a case in any legal respect) seemed to spring from a virulent cocktail of some students' disgruntlement and some journalistic agendas, and it painfully demonstrated that students must be involved and taught the conflicts. Not that this necessarily will prevent similar cases, but if we do not 
spell out the political stuff at stakes and recognize the inherent conflicts that beset our disciplines, I nonetheless fear that we will witness more shadowy 'whistle-blowing' and subterfuge in the future, with paranoia and self-inflicted ostracism looming large instead of candid debates. Let me therefore adduce yet another quotation from Graff and while it is a slightly polemic diagnosis and certainly not pertinent to the Danish situation in every aspect, I think his proposal is worthwhile rethinking:

The best way to prevent students from being bullied by their teachers' political views [and this, of course, should not be taken as a reference to the aforementioned case, $\mathrm{TH}]$ is to bring them into the debates between those views. Students are already being exposed to the violent ideological conflicts of the university every day, but they are exposed to these conflicts in conditions that not only make it difficult for them to join the discussion but create pressure to conform. Then, too, when there is little open debate, teachers readily project paranoid myths about one another, deepening the campus's atmosphere of suspicion and hostility. It may be difficult to eliminate political intimidation and paranoia completely, but a curriculum that presented students with an engagement between the contending political views to which they are exposed would do much to defuse them. This solution will not satisfy those who want to return to an academic and social world whose politics were so uniform that they were not recognized as politics. But it should appeal to the many - left, right, and center.... Instead of pretending we can eliminate political conflict from teaching, we should start making use of it. (Graff: 169-70)

Graff's words could be taken out of a textbook on Agonism. Another example concerns even more heated public issues like, for instance, the cartoon rows (version 1.0 and 2.0). Whereas some commentators and experts have bemoaned that things ever went to a deadlock, I guess that while the conflicts evidently have proved detrimental in the short term, their long-term and possible positive effects are still an option. One of the most experienced authorities on issues related to European Muslims, professor Jørgen S. Nielsen, put forward this estimate fairly recently:

On the other hand, the process of political engagement which may arise out of a growing identification with headline issues in the Muslim world can play an important integrative role, when the issue in question is one which has activated broader sections of society as a whole. One prime example of this in both the United States and in Europe is the movement opposing the 2003 invasion of Iraq. Here there has been a cause where often very angry Muslims have found common ground and shared in common political activity with a wide spectrum of trends in society as a whole. Here they have discovered a route of integration and inclusion in the European public space. I would suggest that, similarly, the controversies provoked by the Muhammad cartoons in Jyllands-Posten a couple of years ago have encouraged an increase in cross-cultural and cross-religious activities in this country. The crisis may thus in the future come to be seen as an integrative event (Nielsen 2008: 11). 
Crisis as mobilising social katarsis is still a fairly disregarded option.

\section{If you desire peace, prepare for war or a note on Agonism}

Having now identified the highly problematic and widespread stance that the political is detrimental and to be bottled up, and having forwarded a didactic plea for scholarly conflict (by dint of Graff and a bit of Horacian poetics), we have reached a moment where we need further theoretical development in terms of social/political science.

Somewhere around the fourth or fifth century the Roman military historian Vegetius wrote these pithy words: "Igitur qui desiderat pacem, praeparet bellum," "if you desire peace, prepare for war." Reinterpreted along the lines of the recent political theory called Agonism (or pluralistic agonism), this provocative and paradoxical dictum, makes sense in the sense that in a foreseeable future a full-blown Hegelian Weltgeist, a Habermasian communicative rationality or even a triumphant market, will never settle itself on the top of a peaceful, academic Olympus. Rather, messy strife and ideological conflict will nearly always be inherent to academic pursuits and 'real' consensus will forever remain at the horizon - in the meantime, petty and provisional consensus may be found. This is the state-of-affairs that must be acknowledged when trying to think out a realistic and politically responsible theory. Agonism is one such attempt. Though this theory usually theorizes grand institutions like democracy, even society, I believe we can convert some of its ambitious insights and arguments and apply them to our intellectual, Islamological circuits. ${ }^{10}$ So, who are these agonists?

First of all, agonists do not constitute a coherent school of thought, yet a common trait among agonists seems to be that they question the plausibility that certain human ideological paradigms and their adjacent discourses - especially liberalism, communitarianism, and pluralism (incl. multiculturalism) - will eventually succeed in containing or circumventing division and conflicts of interests among agents. Instead of bemoaning this inclination as deplorable human condition or, even worse, refusing to acknowledge this inclination and then set for some kind of unfounded optimism and wishful thinking, agonists argue that conflicts and irreconcilable differences should be acknowledged and provided with 'rooms' and 'channels' for playing out these conflicts. The first step to be taken is to acknowledge strife and difference as legitimate, but whereas proto-agonist 
thinkers like Friedrich Nietzsche (1844-1900) and Carl Schmitt (1888-1985) celebrated conflict as the potential arenas where man could dominate, possibly annihilate, his enemies, agonists argue that such final/fatal consequences should be avoided in favour of some form of continuous contestation. In the words of political theorist Bonnie Honig: "to affirm the perpetuity of the contest is not to celebrate a world without points of stabilization; it is to affirm the reality of perpetual contest, even with an ordered setting, and to identify the affirmative dimension of contestation (Honig, 1993, 15). Other agonists, like the post-marxist political scientist Chantal Mouffe, find in the agonistic perspective an acknowledgement of the pluralist project, but instead of pretending that one day, we will happily join hands and celebrate a friendly scholarly pluralism bordering relativism, pluralism instead means that we confront each others' views - head on (even for eggheads). In that respect, my esteemed colleague with whom I might disagree is my professional adversary. Thus Chantal:

the category of the "adversary" requires complexifying the notion of antagonism and distinguishing it from agonism. Antagonism is a struggle between enemies, while agonism is struggle between adversaries... From the perspective of "agonistic pluralism" the aim of democratic politics [read: research positions] is to transform antagonism into agonism. This requires providing channels through which collective passions will be given ways to express themselves over issues, which, while allowing enough possibility for identification will not construct the opponent as an enemy but as an adversary... Far from jeopardizing democracy, agonistic confrontation is in fact its very condition of existence (Mouffe, 2000: 26)

While Mouffe perhaps is overly optimistic on the potentials of Agonism and seems to evade the fact that confrontation can lead to entrenchment and bitter intellectual feuding, I still judge that we must take that risk.

\section{References}

Barrett, David B. (ed.) 1982: World Christian Encyclopedia. A comparative study of churches and religions in the modern world AD 1900-2000. Nairobi: Oxford University Press.

Assmann, Jan, 2003: Die Mosaische Unterscheidung oder Der Preis des Monotheismus, München, Carl Hanser,

Anderson, Benedict, 1991: Imagined Communities: Reflections on the Origin and Spread of Nationalism, rev.ed., London, Verso 
Avalos, Hector, 2005: Fighting Words. The Origins of Religious Violence, Amherst, Prometheus Books.

Ess, Josef van, 2006: The Flowering of Muslim Theology, Cambridge, Harvard University Press.

Fowler; Roger and Günther Kress, 1979: "Critical Linguistics”, Language and Control, Routledge \& Kegan Paul Ltd., London.

Glock, Charles Y. \& Rodney Stark, 1966: Christian Beliefs and Anti-Semitism, Harper and Row, New York.

Graff, Gerald, 1992: Beyond the Culture Wars. How Teaching the Conflicts can Revitalize American Education, New York, W.W. Norton \& Company.

Halliday, Fred, 2005: 100 myths about the Middle East, University of California Press, Berkely.

Hoffmann, Thomas, 2007: The Poetic Qur'ân. Studies on Qur'ânic Poeticity, Harrassowitz: Wiesbaden.

Honig, Bonnie, 1993: Political Theory and the Displacement of Politics, Cornell University Press, New York.

Horace (Quintus Horatius Flaccus) ca. 20 BC: Epistularum Liber Primus. http://www.thelatinlibrary.com/horace/epist1.shtml

Irwin, Robert, 2007: For Lust of Knowing. The Orientalists and their Enemies, Penguin Books, London

Jelloun, Mohammed Ben, 2002: “Agonistic Islam”, Jouvert. A Journal of Postcolonial Studies 6.3. Or http://hem.bredband.net/b287842/\#I3

Jelloun, Mohammed Ben, 2005: “The Agonistic Consociation”, paper presented for the Sixt Essex Graduate Conference in Political Theory, http://hem.bredband.net/b287842/\#I3

Lewis, Bernard, 2003: “I'm Right, You're Wrong, Go To Hell,” in Atlantic Monthly 2003. http://www.theatlantic.com/doc/200305/lewis

Lewinstein, Keith, 2003: "Recent Critical Scholarship and the Teaching of Islam", in Brannon Wheeler (ed.), Teaching Islam, AAR Teaching Religious Studies Series, Oxford University Press, New York.McAuliffe, Jane Dammen, 2004: ““'Reading the Qur'ân with fidelity and freedom" (Presidential Address for the American 


\section{Academy of Religion.}

http://college.georgetown.edu/dean/speeches/JAARpresidentialAddress.pdf)

McCutcheon, Russell T., 2000: “Critics not Caretakers: The Scholar of Religion as Public Intellectual”, Tim Jense \& Mikael Rothstein (eds.): Secular Theories on Religion. Current Perspectives, Museum Tusculanum Press, Copenhagen.

Mouffe, Chantal, 2000: "Deliberative Democracy or Agonistic Pluralism”, in Reihe

Politikwissenschaft 72, Institut für Höhere Studien, Wien.

http://users.unimi.it/dikeius/pw_72.pdf

Nielsen, Jørgen S., 2008: "Islam in Europe: retrenchment and renewal”, Inaugural lecture, University of Copenhagen.

Schmitt, Carl, 1996 (org. 1927): The Concept of the Political, University of Chicago Press, Chicago.

Schwartz, Regina, 1998: The Curse of Cain: the violent legacy of Monotheism, University of Chicago Press, Chicago.

Spirer, Ellen, 1989: "Candidates for Survival. A talk with Harold Bloom”, Boston Review. A political and literary forum. http://bostonreview.net/BR11.1/bloom.html

Wales, Katie, 2001: A Dictionary of Stylistics, Pearson Education Ltd, Essex.

Wheeler, Brannon, 2003: Teaching Islam, AAR Teaching Religious Studies Series, Oxford University Press, New York.

Wiebe, Donald, 1991: The Politics of Religious Studies, New York, St. Martin's.

Thomas Hoffmann, Ph.D., postdoc, Center for European Islamic Thought, University of Copenhagen Research interests: Qur'anic studies, Islam and Muslims in Europe, aesthetics and Islam. Key publications: The Poetic Qur'an. Studies on Qur'anic Poeticity (Harrassowitz: Wiesbaden, 2007); Gads leksikon om islam (Hoffmann and Jean Butler (ed.): Gads Forlag: København, [forthcoming]).

\footnotetext{
${ }_{1}^{1}$ As documented, for instance, by Robert Irwin in his For Lust of Knowledge.

$2 \mathrm{http} / / /$ www.islamforskning.dk/Research_on_Islam_RepositionedMay_2007_call.pdf

${ }^{3}$ A Persian expression meaning 'having no balls.' For a comment on this expression and its life in international politics, see Fred Halliday 2005, 205.

${ }^{4} \mathrm{My}$ construal of the political is much indebted to the political scientist Carl Schmitt and his definition of the political as a field of antagonism; see Schmitt 1927 ff. The political, according to Schmitt, does not
} 
concern a particular subject, but merely denotes the intensity of a conflict. Though notorious for his Nazisympathies, his political thinking has been influential among leftists (e.g., Chantal Mouffe, Georgio Agamben) as well as conservatives (e.g., Leo Strauss).

${ }^{5}$ See e.g., http://www.pbs.org/wnet/religionandethics/week551/sells.html

${ }^{6}$ American think tanks with notable stances on the Middle East and Islamic affairs are e.g. The Investigative Project, Daniel Pipe's Middle East Forum, Cyrus Vance's Iranian American Council, The Ayn Rand Institute.

${ }^{7}$ The Arab notion of adab can be rendered as 'etiquette' or 'good manners.'

${ }^{8}$ I.e., the Thus, Assmann has been connected with the propagation of anti-Semitism by one of Germany's leading Jewish Holocaust-scholars, Micha Brumlik. See e.g., http://www.welt.de/printwelt/article708288/Ist_eine_Spiegel-Titelgeschichte_massiv_antisemitisch.html

${ }^{9}$ The Devil's Dictionary-like definition of tolerance by Lewis: "Tolerance is, of course, an extremely intolerant idea, because it means "I am the boss: I will allow you some, though not all, of the rights I enjoy as long as you behave yourself according to standard that I shall determine" (Lewis 2003)

${ }^{10}$ An exception seems to be Mohammad Ben Jelloun, a young Moroccan-Swedish political scientist from École des Hautes Études en Sciences Sociales, Paris. Jelloun have advocated for the application and development of agonist theory in regard to Islam and Middle Eastern contexts, but the theoretical application is still in the making. See biography. 